\title{
Distinctly African or Dimly African? A reflection on black journalism since 1994
}

Simphiwe Sesanti

THIRTY YEARS have passed since October 19, 1977, when the National Party banned black consciousness organizations and black-oriented newspapers - The World and the Weekend World. What drove the NP regime to such desperate moves was that the majority of black journalists in the 70s unequivocally identified their journalism with the liberation struggle. Black journalists declared themselves "black" first and "journalist" second. They questioned reference to "objectivity" by journalists who called freedom fighters "terrorists". They objected to the misuse of this term by journalists who served in the then South African Defence Force, while they objected to black journalists' identification with the liberation movements. The term "black" was not just a matter of pigmentation but was used in a political context. In his book I Write What I Like, the black consciousness martyr, Bantu Biko, explained the concept of "black" thus: "Merely by describing yourself as black you have started on a road towards emancipation, you have committed yourself to fight against all forces that seek to use your blackness as a stamp that marks you out as a subservient being." Black journalists, therefore, understood blackness to mean, amongst other things, commitment. It is in this line of thinking that the Sowetan, the descendant of The World and Weekend World, was given birth to. The name Sowetan, as observed by the Sowetan's first editor, Joe Latakgomo was identified with the "symbolism of Soweto to identify with the black struggle".

But what of black journalism since 1994? Can black journalists operating in the post-1994 era recognize themselves in Allister Sparks' description of black journalists of the 70s, about whom he says in his book Beyond The Miracle, that black journalists not only reported events of the townships, but brought uniquely black perspectives in the newsrooms?

With typical honesty, the late Editor-In-Chief of the Sowetan, Aggrey Klaaste, in an interview with Chabani Manganyi, observed that with "liberation in 1994, the paper had to find its feet. We frankly did not know what to do next". Perhaps this explains why Sean Jacobs and Richard Calland in their book, Thabo Mbeki's World, refer to the black press as "less influential".

To their credit, though, black journalists have recognized the need to redefine themselves in post-apartheid South Africa. Soon after Mathatha Tsedu took over the editorship of the City Press, he declared the newspaper "Distinctly African". Explaining the concept, Tsedu said that the City Press's role is to enhance the understanding that Africans have of themselves and the rest of the continent, to showcase not just the bad and the evil that happens in Africa, but also the good. But more importantly, Tsedu further observed, "Distinctly African" to the City Press means a commitment to finding good things about Africa so as to inspire and motivate this continent's people. When the City Press declared itself "Distinctly African" some of us where curious in how different the newspaper would be from its Western counterparts who have declared themselves "Distinctly American". A brief illustration is necessary to elucidate my point here. In his book, Rogue State, William Blum observes that during the bombing of Yugoslavia, CBS Evening News anchor, Dan Rather declared: "I'm an American, and I'm an American reporter. And yes, when there's combat involving Americans, you can criticize me if you must, damn me if you must, but I'm always pulling for us to win." This is what has characterized Western journalism, particularly on issues that affected Africa. When commenting on issues about Africa, western journalism has been and 
is often devoid of historical contexts. How "distinctly African" has been the City Press for instance on the wildly and widely publicized Zimbabwean issue?

To his credit, when commenting on the recent beatings of Zimbabwe's Movement for Democratic Change leader, Morgan Tsvangirai, the City Press's current editor, Khathu Mamaila, attempted to give a historical context to the Zimbabwean crisis. Rightly so, he asked the question: what went wrong? Unlike many journalists in South Africa who refused to recognize any good in Mugabe, Mamaila acknowledged that Mugabe started massive educational and developmental programmes. But the City Press's reporting of the "beating of the opposition" was somewhat "dimly African". Of the 16 paragraphs of its story on the beatings, it dedicated only two short paragraphs to the bombing of two policewomen in a police station in Harare who were badly injured. Mugabe's government accused the MDC for the bombing. When the London-published New African published the scarred head of Morgan Tsvangirai and that of the scalded face of Constable Vusani Moyo side by side, Tsvangirai's ordeal paled in comparison. Not differently from other "distinctly Western" newspapers the City Press devoted yet another column space to one Zimbabwean journalist, Tsvangirayi Mukwazhi who told of "his horror at beatings he and MDC members suffered last week" who on seeing Tsvangirai beaten, thought he "was dreaming because I could not imagine this was happening to such an important and respected man in Zimbabwe". No hundred US dollars for guessing where this journalist's sympathies lay! It is so obvious! What is expected from "Distinctly African" newspapers like the City Press is no more or less than what Tsedu himself committed his newspaper to: "We commit to showcasing the good, the evil, the bad and the ugly that happens, and to do so without fear or favour. (italics mine)"

Considering that the question of Zimbabwe has been used to condemn President Thabo Mbeki for most of his time in the office of the president, except for the criticism by South African journalists, there has been little effort in answering Mamaila's appropriate question about "what went wrong". Failure to do so on the part of black journalists is a great disappointment because they - since they were part of the liberation struggle - occupy a unique position to write with a sense of insight and empathy. In dealing with Mbeki's fiercely criticized Quiet Diplomacy, the South African media failed to report the fact that -as former African Union secretary-general, Amara Essy, told the New African - when Mugabe tried to address the land question in 1990 "it was African heads of state who told him to be quiet" since they did not want to "scare the white people in South Africa".

It is against this background that former Mozambican President, Joacquim Chissano told the Sunday Times in July 2003 that "President Mbeki belongs to a team, our team." In clearer terms Chissano was referring to the African heads of states' team, of which Mbeki is part of, which chose a multi-lateral approach as opposed to a unilateral approach. But the South African media, including black journalists, ignored this reality! Had the South African media given this historical background the attention it deserved, light would have been shed on the frequently asked question why it took Mugabe 20 years to address the land question! With all its shortcomings, Suresh Roberts' book, Fit to Govern, must be commended for addressing this question in an enlightening way. In fact Roberts brings in a different and more interesting dimension to the point made by Essy. Roberts notes: "Between 1990 and 1994, as the FW De Klerk propaganda machine attempted to unsettle world opinion by presenting African democracy as a monstrous project, Mugabe was asked by the ANC to delay land reform in Zimbabwe and he agreed. The ten year constitutional moratorium had expired in 1990, the year of Mandela's release." This sorely missing context and dimension is what should set 
apart "Distinctly African" media from the rest.

While the City Press has correctly declared itself "Distinctly African" there are those, like Bill Saidi, deputy editor of The Standard, in Zimbabwe, who argue that "there can be no such thing as African journalism". Really? In advancing his argument in his Friday column in the Sowetan, State We're In, Saidi notes that after Ghana's independence in 1957, "it appeared as if there would be a new animal called African journalism" that "would be different from the journalism of other countries". This African journalism, Saidi continues, "would hear no evil and see no evil in African governance. It would praise the leaders until kingdom come, or until they died, either of natural causes or by the bullet of a soldier or a hired assassin". This description of African journalism that would protect despots is certainly undesirable, but it is wrong on the part of Saidi to throw the water out with the baby. In defining their mission as "Distinctly African" the City Press certainly did not mean that.

While the world shares common problems, there are those that are particular to certain people and must be dealt with in a particular way - hence the need for African journalism.

In her chapter African Politics and American Reporting, in a book entitled Media and Democracy In Africa -edited by Goran Hyden, Michael Leslie and Folu Ogundimu - Beverly Hawk laments the tendency by Western journalists of portraying "African culture as the problem and western institutions as the solution" when dealing with problems of the African continent. She notes that instead of contextualizing African problems, Western journalists tend to reduce African problems to a "tribal problem": "Focusing on tribalism as a problem, therefore, mutes other conflicts of interest between groups and distracts us from covert causes of many African conflicts. Consequently, class conflicts become tribalism; regional conflicts become tribalism; responses to structural adjustment programs become tribalism." Bantu Biko made a similar observation before he left for the ancestral world: "One writer makes the point that in an effort to destroy completely the structures that had been built up in the African Society and to impose their imperialism with an unnerving totality, the colonialists were not satisfied merely with holding a people in their grip and emptying the Native's brain of all form and content, they turned to the past of the oppressed people and distorted, disfigured and destroyed it. No longer was reference made to African culture, it became barbarism. Africa was the 'dark continent'. Religious practices and customs were referred to as superstition. The history of African Society was reduced to tribal battles and internecine wars."

It is against this background that African journalism is required - to contextualize issues and put African culture or cultures into perspective.

In addressing the issue of African culture/s the challenge for black journalists who hold positions of authority is to give space to more black women journalists to address issues of culture. That is because those who are seen as authorities on issues of culture hold power. In many African communities cultural power is political power. Giving more writing space to black women journalists is necessary so that they can begin to challenge the self-serving notions of African culture used by some male chauvinists to entrench ill-gotten privileges. A number of years ago, veteran black woman journalist, Nomavenda Mathiane, pointed out that come 1994, some black male journalists who cried foul against white male journalists only club, have since tasted the sweetness of power, and are following suit. Writing on the 25th anniversary of the City Press, the newspaper's Features Editor, Mapula Sibanda observed: "Today, with the progressive male editor Mathatha Tsedu, each section of the paper has a female writer either leading the pack or making a substantial contribution, save for politics, 
still the preserve of testosterone." Political space should not be the preserve of black male journalists. Black female journalists have just the same right to it as male black journalists have. The challenge facing female black journalists is to copy from the best by forming the black female journalists-only club and challenge the status quo - or else no gender equality! Aluta continua!

(Simphiwe Sesanti lectures at the University of Stellenbosch's Department of Journalism. His journalistic writings have appeared in The Herald, the defunct Evening Post, the Londonpublished New African and the City Press. His autobiography, Carry African, Child (2002 and 2005), was accepted as partial fulfillment by the University of Port Elizabeth)

* The article first appeared in the Rhodes Journal Review, No. 27, 2007 